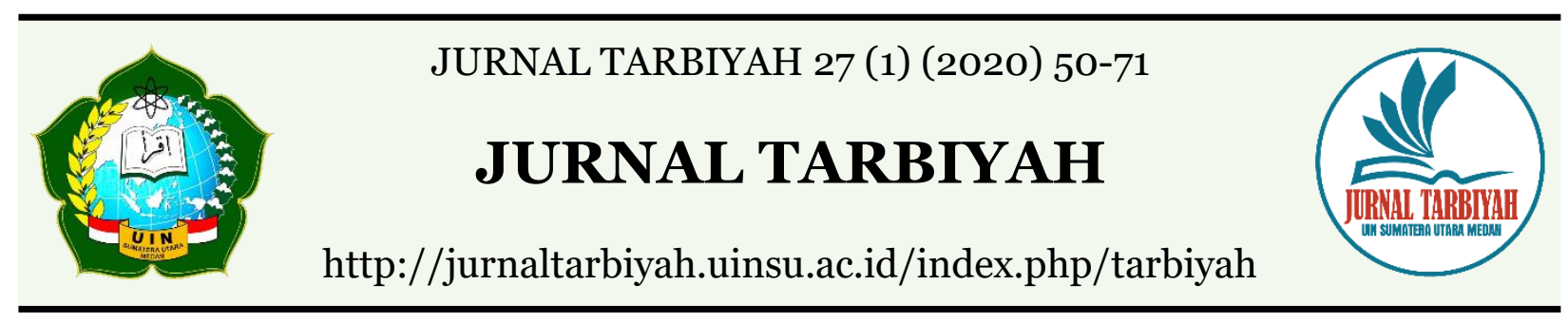

\title{
THE EFFECT OF INDIVIDUAL, GROUP AND TEAM WORK BEHAVIOR TOWARD TEACHER PERFORMANCE IN SMAN 3 MEDAN
}

\author{
Rizki Akmalia', Amiruddin Siahaan², Mesiono3 \\ 1,2,3 Universitas Islam Negeri Sumatera Utara Medan \\ Email: 1rizki.akmalia@gmail.com, ${ }^{2}$ amiruddinsiahaan@uinsu.ac.id, \\ 3mesiono@uinsu.ac.id
}

DOI : 10.30829/tar.v27i1.681

Accepted: March 12th, 2020. Approved: June 25th, 2020. Published: June 3oth, 2020

\begin{abstract}
This study investigates (1) The influence of Individual Behavior TowardTeacher Performance in SMA 3 Medan; (2) The Influence of Group Behavior on Teacher Performance in SMA 3 Medan; (3) The Influence of team work on Teacher Performance in SMA 3 Medan; (4) the influence among Individual, Group and Team Work behavior toward Teacher Performance in SMA Negeri 3 Medan. The results of the study shows that (1) There is a positive and significant influence between $\mathrm{X} 1$ to $\mathrm{Y} 0.9 \%$. It meant that if individual teacher's behavior is getting better in teaching, it will be followed by the increasing of teacher performance in doing their main tasks; (2) There is a positive and significant effect between $\mathrm{X} 2$ and $\mathrm{Y}$ 7.1\%. It is meant that if the behavior of a teacher group in SMA Negeri 3 Medan gives a good example for students, teachers, and the school environment, it will be followed by the increasing of teacher performance in teaching learning process (3) there is a negative effect between $\mathrm{X}_{3}$ to $\mathrm{Y}-0.9 \%$. It can be said that if the work team is good and solid it will not affect the improvement of teacher performance; (4) there is a positive and significant influence between $\mathrm{X}_{1}, \mathrm{X}_{2}$, and $\mathrm{X}_{3}$ together with $\mathrm{Y}$, the correlation coefficient value is 0.303 , $\mathrm{R}$ Square 0.092 and Adjusted R Square 0.057. It shows that the influence of $\mathrm{X} 1, \mathrm{X} 2$, and $\mathrm{X}_{3}$ to $\mathrm{Y}$ is $5.7 \%$ and the remaining $94.3 \%$ is influenced by other factors from variables not included in this study.
\end{abstract}

Keywords: Individual behavior, team work, teacher performance 


\section{INTRODUCTION}

The Organization and human resources (HR) are two parts that need each other and their existence cannot be separated. Human resources are the main key to achieve the goals of organization. Their existence is in the frontline to reach the successful of an organization. In fact, the power of human resources cannot be replaced to any technology. Even though the organization has been stated good either facilities or complete infrastructure. But there are no human resources, it will have no meaning. Basically, the human being only as the actor who plan, conceptualize, manage, and evaluate until the goals of an organization are achieved. Therefore, we need to give good attention to all aspects of human resources either individually or group becomes the most important part in an organization.

It can be denied that the education has an important role in efforts to realize the quality of human resources. In particular, improving of education quality is handed by the teachers as the spearhead in the learning process. Realizing of this situation, teacher performance has an important role in producing of graduation quality.

The Law Number 20 of 2003, concerning to the National Education System mandates that Secondary Education in Chapter VI of Article 18 is a continuation of basic education. Furthermore in Article 18 paragraph 3, it is explained that secondary education consists of general secondary education, and vocational secondary education. Secondary education is High School (SMA), Madrasah Aliyah (MA), Vocational High School (SMK) and Vocational Aliyah Madrasah (MAK) or other (RI Law No. 20 of 2003 concerning the National Education System).

The High School is an educational unit which is organized to prepare students for having ethics, morals, competence, and develop their knowledge higher. Therefore, in requiring of High School needs, the teacher should be competent. In Indonesia Ministry of Education No.16 of 2007 explains that there are four professional teacher competencies. They are followed by pedagogical, professional, social and personality competencies. Through these four competencies, teacher performance can be seen whether increased or static.

There are many factors that affect teacher performance. In the theory of Armstrong and Baron (1998: 16-17) stated that teacher performance can be influenced by individual factors, leadership factors, group / peer / team factors, system factors and contextual / 
situational factors. These factors are the key to the success full of a teacher in achieving the vision and mission of educational organization.

Based on Armstrong and Baron's theory above, personal factors, groups and team work (are used as predictor variables. While the other factors such as leadership factors, system factors, and contextual / situational factors are annulled and not examined.

Regarding to personal factors, each individual is shaped by personality and experience. The personality and experience will be seen and read clearly by the behavior displayed. Adopted from Robbins's theory (2001: 40) that the basic behavior of an individual is based on five variables which are always related to biographical characteristics (age, sex, marital status and years of service), abilities and learnings. Strengthening to the theory above, teacher's behavior in the educational process will give a strong effect and color for fostering student behavior and personality. Therefore, teacher's behavior should be developed to give good influence (Surya, 2004: 90).

Ideally, a teacher must have a personality and behavior based on the Law No. 14 of 2005, in which the teacher has a steady, stable, mature and authoritative personality. In fact, it cannot be denied that each teacher has their own nature and character. It caused by innate different personalities has become part of an organization. The human behavior in the organization comes from two sources. They are individual behavior and group behavior. The group behavior comes from the behavior of individuals who gather into a group. According to the theory Schoper and Galinsky (1955), the group's behavior is an activity related to interesting things which support to one into another, increases creativity and problem solving potential, responsive when under pressure and influence each other, and work together effectively and efficient.

In general, the people who are members of groups in an organization have a strong tendency to seek intimacy, a willing to make a group and working together and need other human beings. It can be seen from the similarity of their tasks in working, the frequent of meeting each other and the similarities in mutual pleasure. Finally, this condition rises closeness each other and start creating of groups to form a team work. The team work is able to improve teacher performance through well-developed collaboration. There are Indicators revealed by West's theory (2002: 93) that work teams have joint responsibility in completing work, contribute to each other and able to exert capacity maximally. Through the indicators above, the work team clearly has an influence in improving teacher performance to be better. 
The low quality and professionalism of teachers in Indonesia, it can be seen from the feasibility of competence when a teacher perform in the class. The Data from the Ministry of Education and Research institute of National Education in 2002-2003 shows that there are only $28.94 \%$ of eligible teachers for state and private elementary schools, $54.12 \%$ state junior high schools, 60.99\% private junior high schools, 65.29\% high schools, private high schools $64.73 \%$, State Vocational School $55.91 \%$ and Private Vocational School 58.26\% (Educational Problems in Indonesia, accessed November 28, 2017 at 21.34 WIB). Based on these data, it can be concluded that the quality of teaching teachers needs improvement through teacher behavior in the teaching and learning process and collaboration between teachers.

The low quality and professionalism of teachers in Indonesia, it can be seen from the feasibility of competence when a teacher perform in the class. The Data from the Ministry of Education and Research institute of National Education in 2002-2003 shows that there are only $28.94 \%$ of eligible teachers for state and private elementary schools, $54.12 \%$ state junior high schools, 60.99\% private junior high schools, 65.29\% high schools, private high schools $64.73 \%$, State Vocational School $55.91 \%$ and Private Vocational School 58.26\% (Educational Problems in Indonesia, accessed November 28, 2017 at 21.34 WIB). Based on these data, it can be concluded that the quality of teaching teachers needs improvement through teacher behavior in the teaching and learning process and collaboration between teachers.

Seeing the importance of the teacher's role in education, teacher performance should be improved. But in fact, the behavior of teachers in SMAN 3 Medan has not fully reflected based on Law No. 14 of 2005 concerning Teachers and Lecturers. In addition, there are still teachers who arrive late and attend only for their teaching hours. It also found that some teachers who do not have teaching skill. They are unable to make learning tools, copy and paste lesson plans, play mobile phones during teaching and learning process. They can speak impolitely, angry to students in public and lack of willing to activate themselves in participating in the Subject Teachers' Conference (MGMP) even though only a small part.

Furthermore, researchers also found that there were a small number of teacher social groups and it was seen during recess time. In general, the behavior of the teaching staff group is already solid and supportive each other, for example participate in MGMP (Subject Teachers' Meeting) either in the school or sub rayon level. But the formation of teacher social group creates incompatibility. However, it can be said that not all MGMP 
(Subject Teachers 'Consultation) activities can run effectively and efficiently. This is caused by the individual's own behavior. They are less active in participating of the MGMP (Subject Teachers' Consultation)

Another obstacle also occurs in administrative costs for each meeting. There are limitations of time and place. There are some educators who not cooperate to solve the problems of education. Meanwhile, the subject teacher and homeroom teacher do not cooperate to help students who have problems and difficulties in teaching learning process.

\section{Review of Related Literature}

\section{Basic Concepts of Individual Behavior}

The behavior is a combination of several psychology factors. These factors are the result of a combination from physical, biological, and social conditions that affect the environment of human life. Each individual was born in different characters. They have its own uniqueness between one into another one. This difference also occurs to the human's behavior. The behavior of individuals in organization can be described on the following diagram:

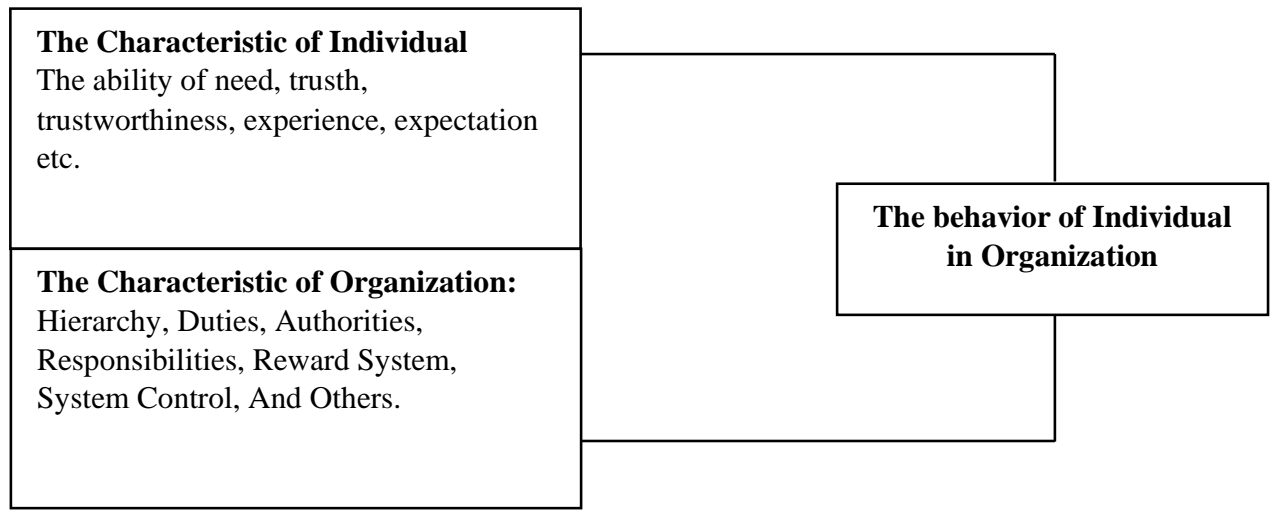

\section{Figure1. The Characteristic of Individual in Organization}

In relation between the individual and the organization, he brought the individual characteristics into the organization. Finally, it builds an interaction between individual characteristics and the characteristics of the organization. Both of interactions embody the behavior of individual. In the Holy Book Al' Quran, the basics of organization has been detailed that one of them us about good behavior in Surah Al-Araf verse 199 and Surah An-Nahl verse 90. 
In addition, Robbin stated that the foundation of individual behavior is about the biographical characteristics (age, sex, marital status and tenure), abilities and learning (Robins, 2001: 40). All of individual behavior is essentially shaped by the personality and experience. There are five individual level variables. They are biographical character, ability, personality, determinants of personality, and learning (Zainal, 2014: 231-235). Individual behavior itself can be influenced by effort, ability and environmental situations (Sopiah, 2008: 23).

\section{Basic Concepts of Group Behavior}

Group can be defined as "A group is at least two individuals gathered together because of some common bond, to meet members' social and emotional needs, or to fulfill some mutual purpose" (Ashman, 2008: 45)

Group is a necessity, inconveniences will arise when one live without grouping. There are a number of reasons for the people join in a group, it include the sense of security, status and self-esteem, interaction and affiliation, strength, goal achievement, and power (Sopiah, 2008: 26-27)

There are several theories relate to group formation including group formation theory which is more comprehensive, namely a theory derived from George Homans. His theory is based on activities, interactions, and sentiments (feelings or emotions) (Homans, 1950)

\section{Basic Concepts of Team Work}

Today, the compactness always considered more important in doing a job than work independently. One of the strengthens in achieving of the goals is from the ability to work in a team, causing a higher solid. It does not rule out the possibility that an organization must have a team work

Team work is a group of people who have the same vision and mission and work together to carry out the realization of the work (Fahmi, 2016: 250). The purpose of forming of team work is due to the desire to speed up a job so that it can finish quickly.

Teams are more effective than individual work. According to West, "there has been a lot of research proved that collaboration in groups leads to better efficiency and effectiveness. This is very different from the work is carried out by individuals "(West, 2002: 93). Work team indicators are responsibilities jointly completing work, 
contributing to each other, and mobilization of abilities to the maximum (West, 2002: 94).

\section{The Differences between Group and Team Work}

Group and team are two different concepts. Work groups are two or more individuals who interacts each other. They share information to make decisions to help one another in their own. In addition, the differences in groups and team work quoted from west will be presented in the table below (West, 2002: 174).

\section{Table 1. The Differences between Group and Team}

\begin{tabular}{|c|c|}
\hline Group & Team \\
\hline $\begin{array}{l}\text { 1. Has a leader, chosen by the members } \\
\text { 2. Individual accountability } \\
\text { 3. The similarity between the goal and } \\
\text { organization } \\
\text { 4. Individual work } \\
\text { 5. The effectiveness is measured by the } \\
\text { business effect indirectly } \\
\text { 6. Discussion, decision, delegation of a } \\
\text { work for each individual }\end{array}$ & $\begin{array}{l}\text { 1. Share the role of leadership } \\
\text { 2. Accountability is mutual and } \\
\text { individual } \\
\text { 3. Vision and mission only for special } \\
\text { team } \\
\text { 4. Collective work } \\
\text { 5. Every meeting opens a discussion } \\
\text { 6. The effectiveness is measured by } \\
\text { directly and collectively } \\
\text { 7. Discussion, decision and sharing of } \\
\text { work }\end{array}$ \\
\hline
\end{tabular}

\section{Basic Concepts of Teacher Performance}

Performance is usually associated with the position relate to one's knowledge, skills and characteristics of one's work behavior. Teacher performance is a condition shows the ability of a teacher in conducting of their duties at school and illustrates an action displayed by the teacher during learning activities.

The low of teacher performance is a trigger which decreases the quality of education and hinders the achievement of the vision of an educational institution. Therefore, teacher performance must be considered and managed properly. In fact, it must always be considered to improve continuously.

There are two important strategies in improve teacher performance, such as training and work motivation. Training is used to handle the low ability of teachers, while performance motivation is used to solve the low morale and enthusiasm in working (Bamawi and Arifin, 2014: 80). Meanwhile, another factors are individual factors, 
leadership factors, group / peer / team factors, system factors, and contextual / situational factors (Armstrong) and Baron, 1998: 16-17).

\section{METHOD OF RESEARCH}

This research was conducted at SMA Negeri 3 Medan which addressed at Jalan Budi Social No. 3 Pulo Brayan, Medan City. The population of this study is teachers in SMA Negeri 3 Medan. The total number is 105 teachers. Taking of sampling used the formula or table Krejcie \& Morgan and became 83 respondents.

This research is designed by using quantitative research through ex post facto technique or model. It aims to prove the effect of the independent variable on the dependent variable, but in this case the researcher does not treat the independent variable. The independent variable is taken on the basis of what has happened in the past.

\section{FINDING AND DISCUSSION}

1. Description

a) Individual Behavior $\left(\mathrm{X}_{1}\right)$

The result from individual behavior variables (X1) from 28 items gives the data consist of the highest score of 130, the lowest score of 98, mean 113.55, standard deviation of 8,670 and variance of 75,177 . The data shows that the average and mode media is not much different. This is an indication that the frequency distribution of variable $\mathrm{X} 1$ is normally distributed.

The following diagram will illustrates the frequency of Individual Behavior data:

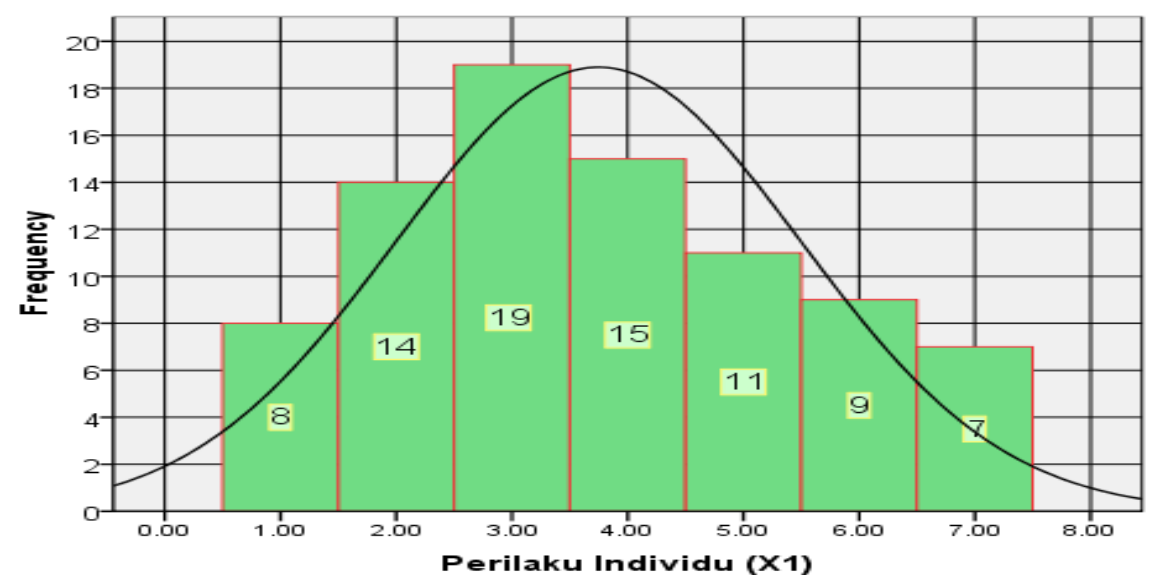

Mean $=3.75$
Std. Dev
$\mathbb{N}=83.7 .752$

Figure 2: The Histogram of individual behavior score 
b) Variable of Group Behavior $\left(\mathrm{X}_{2}\right)$

The results of group behavior variables (X2) from 24 items of statement items provide the data which consists of the highest score of 120 , the lowest score of 87 , mean 105.76, standard deviation of 8,516 and variance of 72,527 . The data shows the average and between mode and median is not much different. This is an indication that the frequency distribution of group behavior variable is normally distributed.

The following diagram illustrates the frequency of group behavior $\left(\mathrm{X}_{2}\right)$

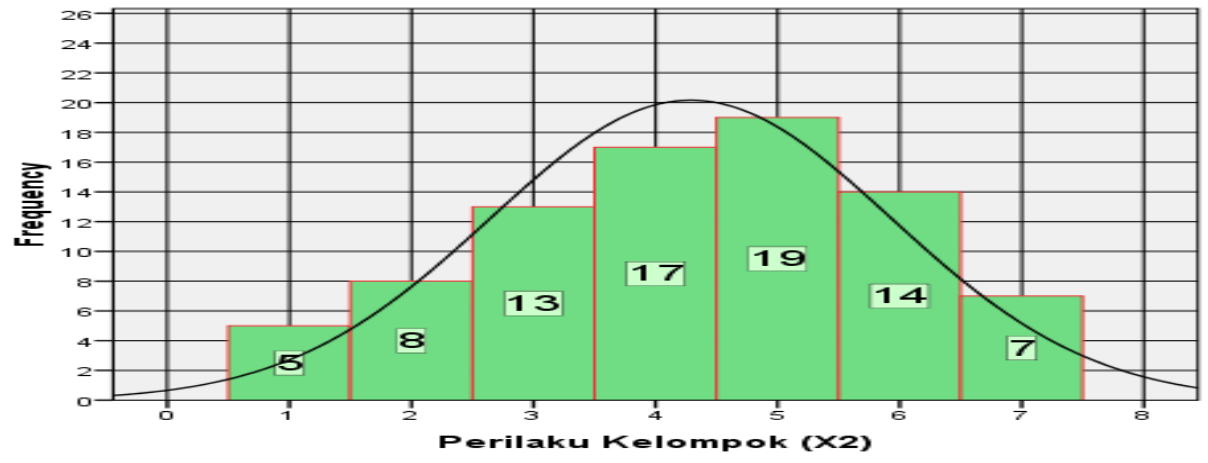

Figure 3. Histogram of group behavior score $\left(\mathrm{X}_{2}\right)$

c). Variable of Team Work $\left(\mathrm{X}_{3}\right)$

The results of the Team work variable $\left(\mathrm{X}_{3}\right)$ from 24 items provide the distribution of data with the highest score of 119 , the lowest score of 86 , the mean of 100.69, the standard deviation of 9,556 , and the variance of 91,315 . The data shows the mean and mode not much different. This is an indication that the variable frequency of team work is normally distributed. The following graphic illustrates the frequency of team work.

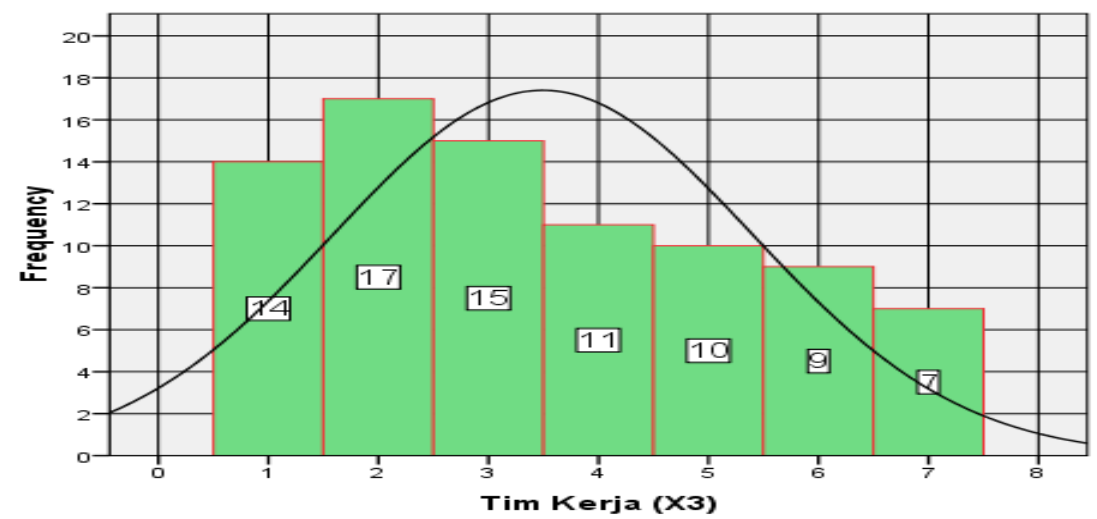

Figure 4 : Histogram of Team Work Score (X3) 


\section{d). The Variable of Teacher Performance}

The results of teacher Performance variables (Y) from 29 items give the distribution of data with the highest score of 137 , the lowest score of 96 , the mean 116.70 , the standard deviation of 10,334 and the variance of 106,798. The data shows the average and mode with a median is not much different. This is an indication that the frequency of teacher performance variables is normally distributed. The following graphic illustrates the frequency of teacher performance.

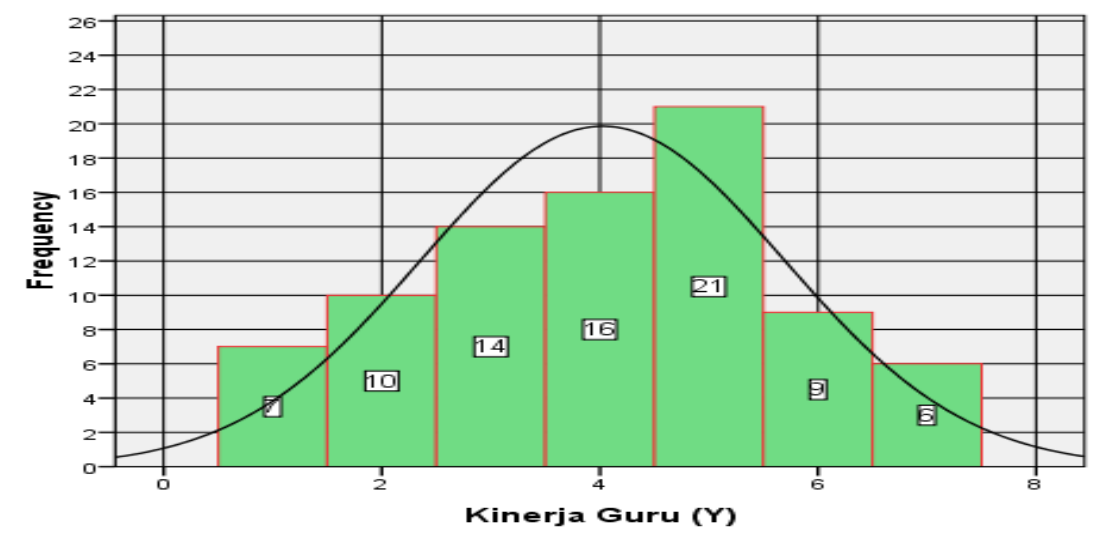

Figure 5: Histogram of Teacher Performance Score (y)

\section{Testing of Requirements Analysis}

a. Normality Test by using Kolmogorov-Smirnov

Table 2. One-Sample Kolmogorov-Smirnov Test

\begin{tabular}{|l|l|c|c|c|c|}
\hline \multicolumn{2}{|l|}{} & $\mathbf{X 1}$ & $\mathbf{X 2}$ & $\mathbf{X 3}$ & $\mathbf{Y}$ \\
\hline $\mathrm{N}$ & 83 & 83 & 83 & 83 \\
\hline \multirow{2}{*}{ Normal Parameters } & $\mathrm{a}$ \\
& Mean & 113.55 & 105.76 & 100.69 & 116.70 \\
\cline { 2 - 6 } & Std. Deviation & 8.670 & 8.516 & 9.556 & 10.334 \\
\hline $\begin{array}{l}\text { Most Extreme } \\
\text { Differences }\end{array}$ & Absolute & .079 & .082 & .098 & .095 \\
\cline { 2 - 6 } & Positive & .074 & .053 & .098 & .059 \\
\cline { 2 - 6 } & Negative & -.079 & -.082 & -.067 & -.095 \\
\hline \multicolumn{2}{|l|}{ Kolmogorov-Smirnov Z } & .716 & .747 & .890 & .866 \\
\hline \multicolumn{2}{|l|}{ Asymp. Sig. (2-tailed) } & .684 & .633 & .406 & .441 \\
\hline
\end{tabular}


a. Distribution Test is Normal.

Based on the Asymp Sig. (2-tailed) above, it can be concluded that the four research variables shape a normal distribution toward population. The data is normally distributed if the Asymp Sig. (2-tailed)> 0.05.

b. Test for Homogeneity

Based on processing of the data by using the Lavene test, it shows that the count lavene test is 1.439 with a probability value (p) 0.146 (X1), 1.424 with a probability value (p) 0.142 (X2), 2.095 with a probability value (p) 0.111 (X3). Thus, based on the testing criteria, if the probability value (p)> 0.05, then the variables of individual, group and team work behavior come from populations who have the same variance (homogeneous). For details of Lavene test data can be seen in the table below:

Table 3. Homogenity Test of Variances

\begin{tabular}{|c|c|c|c|c|}
\hline \multicolumn{2}{|r|}{ Levene Statistic } & df1 & df2 & Sig. \\
\hline $\mathrm{X}_{1}$ & 1.439 & 18 & 62 & $\mathbf{. 1 4 6}$ \\
\hline $\mathrm{X}_{2}$ & 1.424 & 22 & 59 & $\mathbf{. 1 4 2}$ \\
\hline $\mathrm{X}_{3}$ & 2.095 & 25 & 55 & $\mathbf{. 1 1 1}$ \\
\hline
\end{tabular}

b. Test for Linearity

1. Linearity Test Between $\mathrm{X} 1$ and $\mathrm{Y}$

Related to the requirements of the linearity test that if the probability (sig)> 0.05, then the correlation between the independent and dependent variables is linear. Based on these criteria, it can be concluded that the correlation between individual behavior variables (X1) and teacher performance variables (Y) is linear.

Table 4. Linearity Test for Individual Behavior Variables (X1)

\begin{tabular}{|l|l|l|c|c|c|c|c|}
\hline \multicolumn{2}{|c|}{ ANOVA } \\
\hline \multirow{2}{*}{} & & $\begin{array}{c}\text { Sum of } \\
\text { Squares }\end{array}$ & $\begin{array}{c}\text { Mean } \\
\text { Square }\end{array}$ & F & Sig. \\
\hline $\begin{array}{l}\text { Teacher } \\
\text { Performance } \\
\begin{array}{l}\text { Individual } \\
\text { behavior }\end{array}\end{array}$ & $\begin{array}{l}\text { Between } \\
\text { Groups }\end{array}$ & (Combined) & 2751.763 & 20 & 137.588 & 1.420 & .147 \\
\cline { 3 - 9 } & Linearity & 188.112 & 1 & 188.112 & 1.942 & .168 \\
\cline { 2 - 8 } & $\begin{array}{l}\text { Deviation from } \\
\text { Linearity }\end{array}$ & 2563.651 & 19 & 134.929 & 1.393 & $\mathbf{. 1 6 4}$ \\
\hline
\end{tabular}


Rizki Akmalia, Amiruddin Siahaan, Mesiono / JURNAL TARBIYAH 27 (1) (2020) 50-71

\begin{tabular}{|l|l|l|l|l|l|l|}
\hline \multirow{2}{*}{ Within Groups } & 6005.707 & 62 & 96.866 & & \\
\cline { 2 - 7 } & Total & 8757.470 & 82 & & & \\
\hline
\end{tabular}

2. Linearity Test Between $\mathrm{X}_{2}$ and $\mathrm{Y}$

Deal to the requirements of the linearity test that if the probability (sig) $>0.05$, then the correlation between the independent and dependent variables is linear. Based on these criteria, it can be concluded that the correlation between the group behavior variable (X2) and the teacher performance variable $(\mathrm{Y})$ is linear.

Table 5. The Result of Linearity Test for Group Behavior Variable $\left(\mathrm{X}_{2}\right)$

\begin{tabular}{|c|c|c|c|c|c|c|c|}
\hline \multicolumn{8}{|c|}{ ANOVA Table } \\
\hline & & & $\begin{array}{l}\text { Sum of } \\
\text { Squares }\end{array}$ & df & $\begin{array}{c}\text { Mean } \\
\text { Square }\end{array}$ & $\mathbf{F}$ & Sig. \\
\hline \multirow{3}{*}{$\begin{array}{l}\text { Teacher } \\
\text { Performance }\end{array}$} & \multirow{3}{*}{$\begin{array}{l}\text { Between } \\
\text { Groups }\end{array}$} & (Combined) & 3811.970 & 23 & 165.738 & 1.977 & .019 \\
\hline & & Linearity & 721.172 & 1 & 721.172 & 8.604 & .005 \\
\hline & & $\begin{array}{l}\text { Deviation from } \\
\text { Linearity }\end{array}$ & 3090.798 & 22 & 140.491 & 1.676 & .060 \\
\hline \multirow{2}{*}{ Behavior } & \multicolumn{2}{|c|}{ Within Groups } & $4945 \cdot 500$ & 59 & 83.822 & & \\
\hline & \multicolumn{2}{|l|}{ Total } & 8757.470 & 82 & & & \\
\hline
\end{tabular}

3. Testing for Linearity between $X_{3}$ and $Y$

Connected to the requirements of the linearity test that if the probability (sig)> 0.05, then the correlation between the independent and dependent variables is linear. Based on these criteria, it can be concluded that the correlation between the variable of team work $\left(\mathrm{X}_{3}\right)$ and teacher performance $(\mathrm{Y})$ is linear.

Table 6. Results of Linearity Test for Team Work Variables ( $\left.\mathrm{X}_{3}\right)$

\begin{tabular}{|c|l|l|c|c|c|c|c|}
\hline \multicolumn{7}{|c|}{ ANOVA Table } \\
\hline & & $\begin{array}{c}\text { Sum of } \\
\text { Squares }\end{array}$ & df & $\begin{array}{c}\text { Mean } \\
\text { Square }\end{array}$ & F & Sig. \\
\hline & & (Combined) & 2737.103 & 27 & 101.374 & .926 & .576 \\
\hline
\end{tabular}


Rizki Akmalia, Amiruddin Siahaan, Mesiono / JURNAL TARBIYAH 27 (1) (2020) 50-71

\begin{tabular}{|c|c|c|c|c|c|c|c|}
\hline \multirow{4}{*}{$\begin{array}{l}\text { Teacher } \\
\text { Performance } \\
\text { * Team } \\
\text { Work }\end{array}$} & \multirow{2}{*}{$\begin{array}{l}\text { Between } \\
\text { Groups }\end{array}$} & Linearity & 30.535 & 1 & 30.535 & 279 & .600 \\
\hline & & $\begin{array}{l}\text { Deviation from } \\
\text { Linearity }\end{array}$ & 2706.568 & 26 & 104.099 & .951 & .543 \\
\hline & \multicolumn{2}{|c|}{ Within Groups } & 6020.367 & 55 & 109.461 & & \\
\hline & \multicolumn{2}{|l|}{ Total } & 8757.470 & 82 & & & \\
\hline
\end{tabular}

\section{Testing of Hypotheses}

a) First Hypothesis, Individual Behavior Gives a Significant Effect on the Performance of Teachers of SMA Negeri 3 Medan.

The result analysis of individual behavior (X1) on teacher performance $(\mathrm{Y})$ is found by using simple linear regression analysis. It can be seen on the following table .

Table 7. The Result of Regression Analisis $\mathrm{X}_{1}$ Toward Y

\begin{tabular}{|c|c|r|r|r|r|r|r|r|r|}
\hline \multicolumn{10}{|c|}{ Model Summary } \\
\hline \multirow{2}{*}{ Model } & $\mathbf{R}$ & $\begin{array}{c}\text { R } \\
\text { Square }\end{array}$ & $\begin{array}{c}\text { Adjusted R } \\
\text { Square }\end{array}$ & $\begin{array}{c}\text { Std. Error } \\
\text { of the } \\
\text { Estimate }\end{array}$ & $\begin{array}{c}\text { R Square } \\
\text { Change }\end{array}$ & F Change & dfi & df2 & $\begin{array}{c}\text { Sig. F } \\
\text { Change }\end{array}$ \\
\hline 1 & $.147^{\mathrm{a}}$ & .021 & .009 & 10.286 & .021 & 1.778 & 1 & 81 & .018 \\
\hline
\end{tabular}

a. Predictors: (Constant), Individual Behavior

The table above shows that the results of a simple linear regression. The calculation defines that $\mathrm{R}$ is 0.147 , the strength of the relationship ( $\mathrm{R}$ Square)occurs between variables of 0.021 and the coefficient of determination (Adjusted R Square) of 0.009. It is meant that individual behavior has an influence on the performance of teachers in Medan 3 High Schools, seem at the total score is $0.009 \times 100 \%=0.9 \%$. Simply, it can be concluded that if the individual behavior of each teachers in SMA Negeri 3 Medan look better, it will influence to the improvements of teacher performance. The following table shows the similarity of regression on individual behavior variables (X1). 
Table 8. Equation of Simple Linear Regression X1

\begin{tabular}{|c|c|c|c|c|c|c|}
\hline \multicolumn{7}{|c|}{ Coefficients $^{\mathbf{a}}$} \\
\hline & \multirow[t]{2}{*}{ Model } & \multicolumn{2}{|c|}{$\begin{array}{c}\text { Unstandardized } \\
\text { Coefficients }\end{array}$} & \multirow{2}{*}{$\begin{array}{c}\begin{array}{c}\text { Standardized } \\
\text { Coefficients }\end{array} \\
\text { Beta }\end{array}$} & \multirow[t]{2}{*}{$\mathbf{t}$} & \multirow[t]{2}{*}{ Sig. } \\
\hline & & $\mathbf{B}$ & Std. Error & & & \\
\hline \multirow[t]{2}{*}{1} & (Constant) & 96.862 & 14.919 & & 6.493 & .000 \\
\hline & Individual behavior & .175 & .131 & .147 & 1.333 & .018 \\
\hline
\end{tabular}

Based on the above table, the model of equation on linear regression seems on the following:

$$
\hat{Y}=96,862+0,175 X 1
$$

The following is the points of the two interrelated variables in smple linear regression.

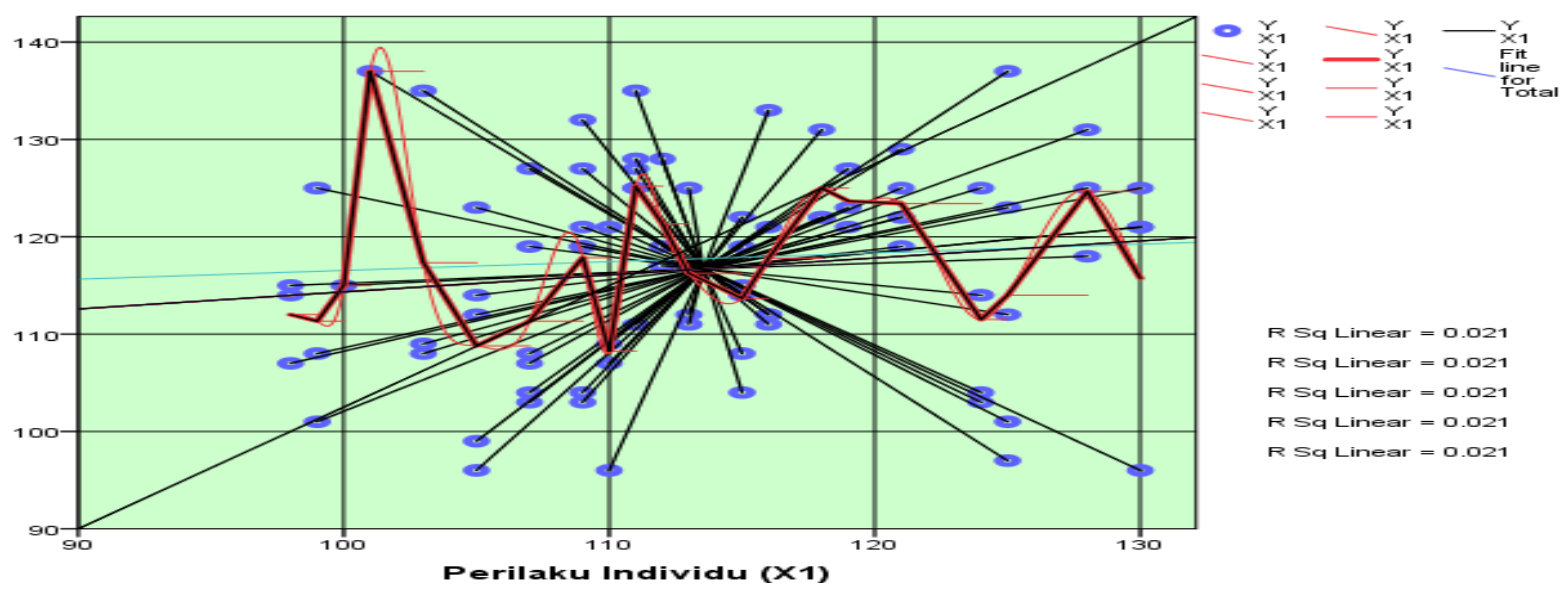

Figure 6. Regression of Individual Behavior Variables (X1)

From the picture above shows that the points of influence between individual behavior variables on teacher performance spreads on the whole points from left to bottom and right. This occurrence means the better individual behavior of teachers in teaching, the better for teacher performance. The influence between the variable (X1) against $(\mathrm{Y})$ is $0.9 \%$ and it can be seen at the estimation points located right on the diagonal line. 
b). The second hypothesis, Group Behavior Gives a Significant Effect on the Performance of Teachers of SMA Negeri 3 Medan

In finding of the result analysis between the group behavior (X2) towards the teacher performance $(\mathrm{Y})$, this reseacr used simple linear regression analysis. The results of the analysis can be seen below:

Table 9. The Result of Regression $\mathbf{X}_{\mathbf{2}}$ Toward Y

\begin{tabular}{|c|c|c|c|c|c|c|c|c|c|}
\hline \multicolumn{10}{|c|}{ Model Summary } \\
\hline \multirow[b]{2}{*}{ Model } & \multirow[b]{2}{*}{$\mathbf{R}$} & \multirow{2}{*}{$\begin{array}{c}\text { R } \\
\text { Square }\end{array}$} & \multirow{2}{*}{$\begin{array}{l}\text { Adjusted } \\
\text { R Square }\end{array}$} & \multirow{2}{*}{$\begin{array}{c}\text { Std. Error } \\
\text { of the } \\
\text { Estimate }\end{array}$} & \multicolumn{5}{|c|}{ Change Statistics } \\
\hline & & & & & $\begin{array}{c}\text { R Square } \\
\text { Change }\end{array}$ & $\begin{array}{c}\text { F } \\
\text { Change }\end{array}$ & dfi & df2 & $\begin{array}{c}\text { Sig. F } \\
\text { Change }\end{array}$ \\
\hline 1 & $.287^{\mathrm{a}}$ & .082 & .071 & 9.961 & .082 & 7.269 & 1 & 81 & .009 \\
\hline \multicolumn{5}{|c|}{ a. Predictors: (Constant), group behavior } & & & & & \\
\hline
\end{tabular}

The table above defined that the results of a simple linear regression show an $\mathrm{R}$ is 0.287 , the strength of the relationship ( $\mathrm{R}$ Square)occurs between variables of 0.082 and the coefficient of determination (Adjusted R Square) of (0.071). It is meant that group behavior influences the performance of teachers in Medan 3 High Schools, the total number is $0.071 \times 100 \%=7.1 \%$. Simply, it can said that if the behavior of a teacher group give a good example for students, teachers and the school environment, it will increase teacher performance. The regression equation for group behavior variables (X2) can be seen from the following table:

Table 10. Regression Equation For Group Behavior Variables (X2)

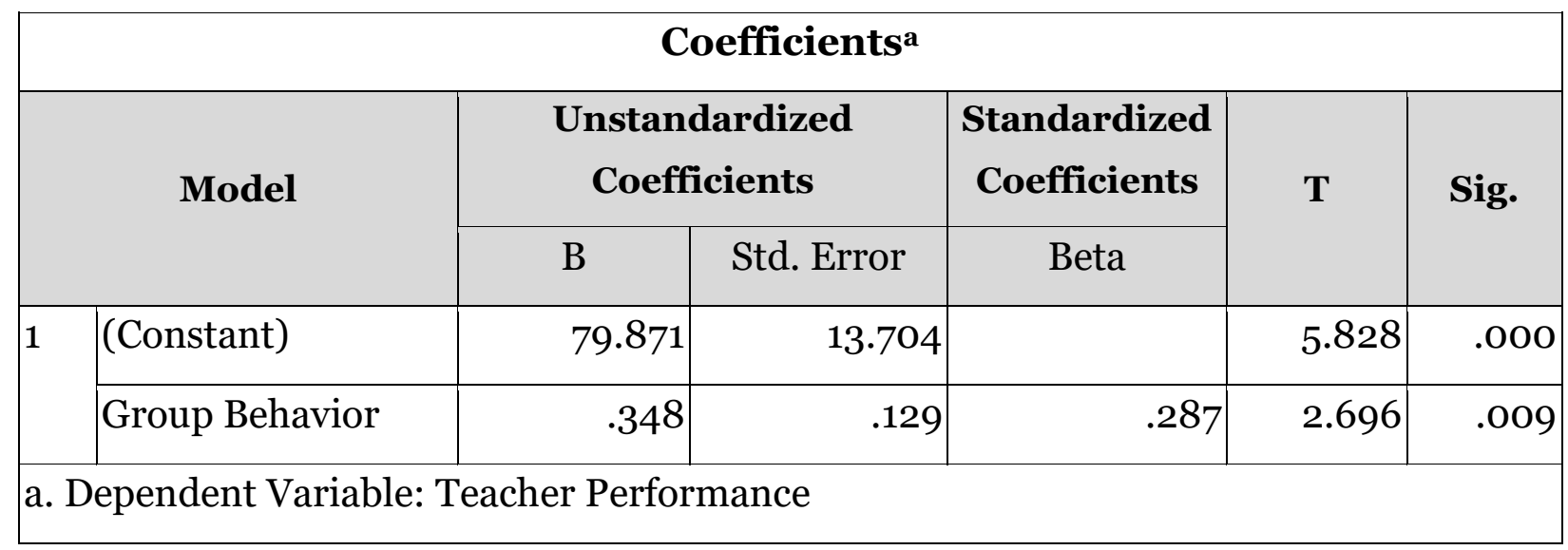


Based on the table above, the Linear regression equation model is formed as follows

$$
\hat{\mathbf{Y}}=79,871+0,348 \mathrm{X}_{2}
$$

To see the distribution of points from the two interrelated variables, the following table is estimation of simple linear regression toward the group behavior variable (X2).

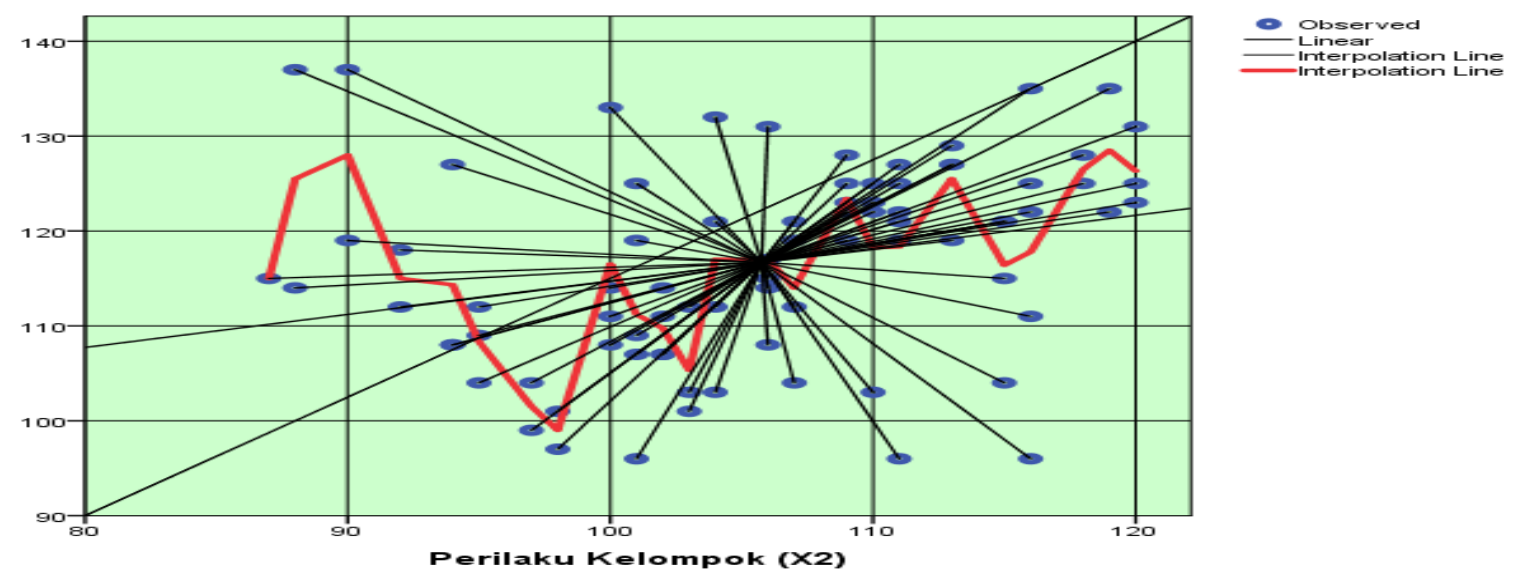

Figure 7. Regression Estimation of Group Behavior Variables (X2)

The picture above describes that the points of influence between group behavior variables on teacher performance spreads on whole points from left to bottom and right. This occurrence means that the better of group behavior will impact the better of teacher performance. The effect from the variable $\left(\mathrm{X}_{2}\right)$ and $(\mathrm{Y})$ is $7.1 \%$ and this can be seen at the estimation points which are located right on the diagonal line.

c) The Third, Team Work Gives a Significant Effect on Teacher Performance

In finding of the result between team work $\left(\mathrm{X}_{3}\right)$ on teacher performance, this study use simple linear regression analysis. The results of the analysis can be seen below:

Table 11. The Result of Regression $\mathbf{X}_{\mathbf{3}}$ Toward Y

\begin{tabular}{|c|c|c|c|c|c|c|c|c|c|}
\hline \multirow[b]{2}{*}{ Model } & \multirow[b]{2}{*}{$\mathbf{R}$} & \multirow[b]{2}{*}{$\begin{array}{c}\text { R } \\
\text { Square }\end{array}$} & \multirow{2}{*}{$\begin{array}{l}\text { Adjusted } \\
\text { R Square }\end{array}$} & \multirow{2}{*}{$\begin{array}{l}\text { Std. Error } \\
\text { of the } \\
\text { Estimate }\end{array}$} & \multicolumn{5}{|c|}{ Change Statistics } \\
\hline & & & & & $\begin{array}{c}\text { R Square } \\
\text { Change }\end{array}$ & $\begin{array}{c}\text { F } \\
\text { Change }\end{array}$ & dfi & df2 & $\begin{array}{c}\text { Sig. F } \\
\text { Change }\end{array}$ \\
\hline 1 & $.059^{a}$ & .003 & -.009 & 10.380 & .003 & .283 & 1 & 81 & .596 \\
\hline \multicolumn{5}{|c|}{ a. Predictors: (Constant), Team Work } & & & & & \\
\hline
\end{tabular}




$$
\hat{Y}=96,862+0,175 X_{1}
$$

The table above describes that the results of a simple linear regression calculation show an $\mathrm{R}$ is 0.059 , the strength of the relationship ( $\mathrm{R}$ Square) occurs between variables is 0.003 and the coefficient of determination (Adjusted R Square) is (-o.oog). It means that teamwork has a negative influence on teacher performance by the score (-0.009) $\mathrm{x}$ $100 \%=-0.9 \%$. Simply, it means that if the team work shows getting better and solid, then it will not affect the merits of the teacher's performance. The following table shows the equation of regression on variable of team work.

Table12. The Equation of Simple Linear Regression X3

\begin{tabular}{|c|c|c|c|c|c|c|}
\hline \multicolumn{7}{|c|}{ Coefficients $^{a}$} \\
\hline & \multirow[t]{2}{*}{ Model } & \multicolumn{2}{|c|}{$\begin{array}{l}\text { Unstandardized } \\
\text { Coefficients }\end{array}$} & \multirow{2}{*}{$\begin{array}{c}\begin{array}{c}\text { Standardized } \\
\text { Coefficients }\end{array} \\
\text { Beta }\end{array}$} & \multirow[t]{2}{*}{ t } & \multirow[t]{2}{*}{ Sig. } \\
\hline & & B & Std. Error & & & \\
\hline 1 & (Constant) & 110.269 & 12.131 & & 9.090 & .000 \\
\hline & Tim Kerja & .064 & .120 & .059 & .532 & .596 \\
\hline & dent Var & Teach & formance & & & \\
\hline
\end{tabular}

Based on the table above, the model of Linear regression equation formed as follows:

$$
\hat{\mathbf{Y}}=110,269+0,064 \mathrm{X}_{3}
$$

To see the distribution of points from the two interrelated variables, the picture below will see the estimation of simple linear regression on the team work variable $\left(\mathrm{X}_{3}\right)$ 

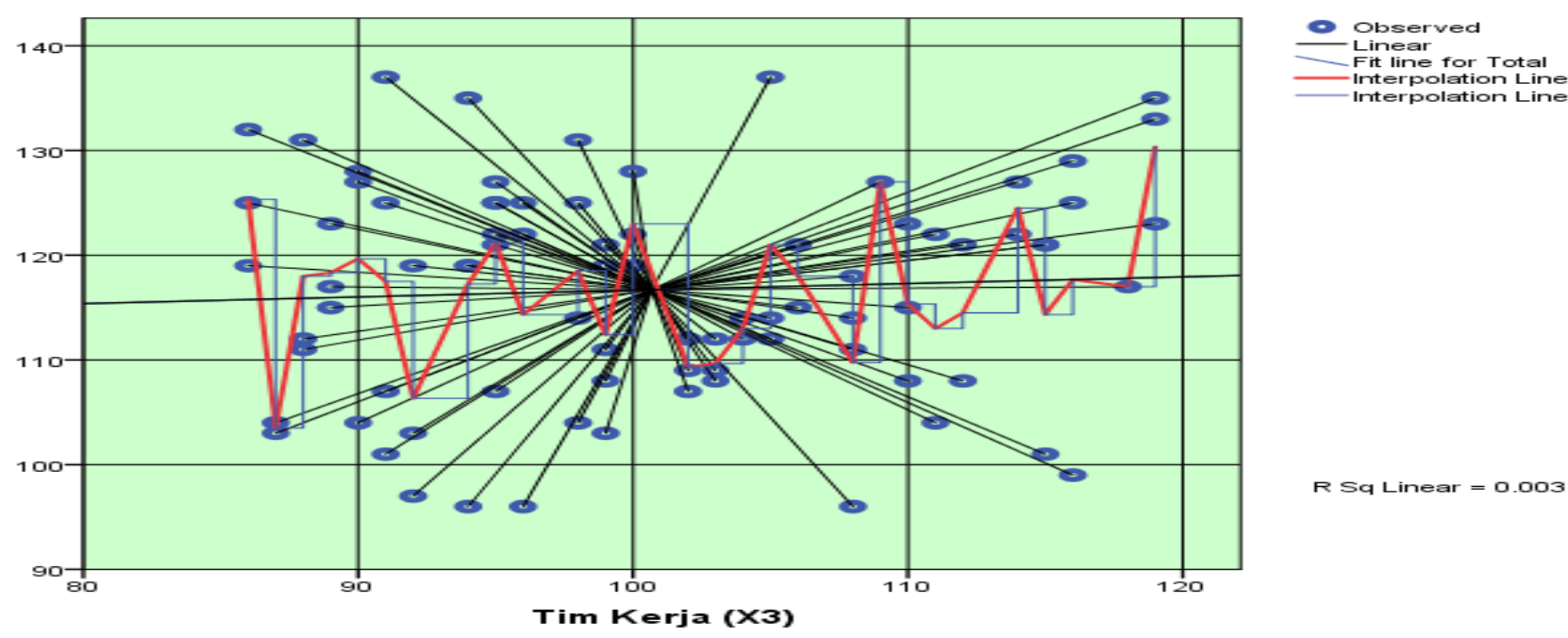

Figure 8. Estimation of Team Variable Regression ( $\left.\mathrm{X}_{3}\right)$

From the picture above, it can be seen that the points of partnership widen and move away give an indication that the team work variable does not influence teacher performance. The whole points distributed from left to bottom, right and above. It shows the occurrence of phenomena occurs in the solid and compability of teaher team work in SMA Negeri 3 Medan. But it will not affect the level of teacher performance in teaching. The influence which is given between the variable $\left(\mathrm{X}_{3}\right)$ to $(\mathrm{Y})$ is $(-0.9 \%)$ and it can be seen at the estimated points are spread on the diagonal line.

d) Fourth Hypothesis; Individual, Group Behavior and team work gives Significant Influence on Teacher Performance in SMA Negeri 3 Medan

To see the relationship in this fourth hypothesis, multiple linear regression analysis is used in order to find out whether the relationship between these variables is predictive or not. Meanwhile, the significance can be determined by the $\mathrm{F}$ test. The results of the multiple correlation analysis and the correlation coefficient significance can be seen in the table below:

Table13. The Equation of Double Linear Regression Between X1, X2, and X3 toward Y

\begin{tabular}{|l|c|r|r|r|r|r|r|r|r|}
\hline \multicolumn{10}{|c|}{ Model Summary } \\
\hline Model & $\mathbf{R}$ & $\begin{array}{c}\text { R } \\
\text { Square }\end{array}$ & $\begin{array}{c}\text { Adjusted } \\
\text { R Square }\end{array}$ & $\begin{array}{c}\text { Std. Error } \\
\text { of the } \\
\text { Estimate }\end{array}$ & $\begin{array}{c}\text { R Square } \\
\text { Change }\end{array}$ & $\begin{array}{c}\text { F } \\
\text { Change }\end{array}$ & df1 & df2 & $\begin{array}{c}\text { Sig. F } \\
\text { Change }\end{array}$ \\
\hline 1 & $.303^{\mathrm{a}}$ & .092 & .057 & 10.033 & .092 & 2.665 & 3 & 79 & .045 \\
\hline
\end{tabular}

a. Predictors: (Constant), team work, individual behavior and group individual 
Table 14. Models of Double Linear Regression Equations

between $\mathrm{X}_{1}, \mathrm{X}_{2}$, and $\mathrm{X}_{3}$ toward $\mathrm{Y}$

\begin{tabular}{|c|c|c|c|c|c|c|}
\hline & \multicolumn{6}{|c|}{ Coefficients ${ }^{\mathbf{a}}$} \\
\hline & \multirow[t]{2}{*}{ Model } & \multicolumn{2}{|c|}{$\begin{array}{c}\text { Unstandardized } \\
\text { Coefficients }\end{array}$} & \multirow{2}{*}{$\begin{array}{c}\text { Standardized } \\
\text { Coefficients } \\
\text { Beta }\end{array}$} & \multirow[t]{2}{*}{$\mathbf{t}$} & \multirow[t]{2}{*}{ Sig. } \\
\hline & & $\mathbf{B}$ & Std. Error & & & \\
\hline \multirow[t]{4}{*}{1} & (Constant) & 66.599 & 20.902 & & 3.186 & .002 \\
\hline & Individual Behavior & .112 & .130 & .094 & .857 & .394 \\
\hline & Group Behavior & .323 & .133 & .266 & 2.429 & .017 \\
\hline & Team work & .032 & .117 & .030 & .277 & .782 \\
\hline \multicolumn{6}{|c|}{ a. Dependent Variable: teacher performance } & \\
\hline
\end{tabular}

Based on the table above, the model of double regression formed as follows:

$$
\hat{Y}=66,599+0,112 X_{1}+0,323 X_{2}+0,032 X_{3}
$$

The constant ( $\alpha$ ) of 66,599 means that if the research variables (individual, group and team work behavior) are considered constant, the teacher's performance will increase. The coefficient of variable regression $\mathrm{X} 1$ is 0.112 (positive). It states that each addition of an individual behavior, while other factors are considered constant, then the teacher performance will increase into 0.112.

Furthermore, the regression coefficient of variable X2 is 0.323 (positive). It states that if there is an increasing in a group behavior, while other factors are considered constant, then the teacher performance of the SMA 3 Medan will increase into 0.323. Meanwhile the regression coefficient of variable $\mathrm{X}_{3}$ is 0.032 (positive). It defines that each addition of one team work while other factors are considered constant, then the performance of teachers will increase into 0.032.

Table 15. Test of F between X1, X2, and X3 toward Y

\begin{tabular}{|c|c|c|c|c|c|c|}
\hline \multicolumn{7}{|c|}{ ANOVA $^{b}$} \\
\hline & Model & Sum of Squares & df & Mean Square & $\mathbf{F}$ & Sig. \\
\hline 1 & Regression & 804.791 & 3 & 268.264 & 2.665 & $.045^{\mathrm{a}}$ \\
\hline
\end{tabular}


Rizki Akmalia, Amiruddin Siahaan, Mesiono / JURNAL TARBIYAH 27 (1) (2020) 50-71

\begin{tabular}{|l|l|r|r|r|r|l|}
\hline & Residual & 7952.679 & 79 & 100.667 & & \\
\cline { 2 - 6 } & Total & 8757.470 & 82 & & & \\
\hline \multicolumn{2}{l|}{ a. Predictors: (Constant), $\mathrm{X}_{3}, \mathrm{X}_{1}, \mathrm{X}_{2}$} & & & & \\
\hline b. Dependent Variable: $\mathrm{Y}$ & & & & \\
\hline
\end{tabular}

From the Anova test (F-Test), the calculated $\mathrm{F}$ is 2.665 with a significance level of 0.045 , because of the probability is smaller <0.05. This indicates that the behavior of individuals (X1), groups (X2) and team work ( $\left.\mathrm{X}_{3}\right)$ together have a positive and significant effect on teacher performance $(\mathrm{Y})$.

Tabel 16. Model of Summary adjusted R Square

Between $\mathrm{X}_{1}, \mathrm{X}_{2}$, dan $\mathrm{X}_{3}$ Toward $\mathrm{Y}$

\begin{tabular}{|c|c|c|c|c|}
\hline Model & $\mathrm{R}$ & R Square & $\begin{array}{l}\text { Adjusted R } \\
\text { Square }\end{array}$ & Std. Error of the Estimate \\
\hline 1 & $.303^{\mathrm{a}}$ & .092 & .057 & 10.033 \\
\hline
\end{tabular}

The coefficient of determination (Adjusted R Square) of 0.057 indicates that the influence of individual, group and team work behavior on the teacher performance in Senior High School 3 Medan is $5.7 \%$ and the remaining $94.3 \%$. it is estimated comes from variables does not included in this study.

The analysis above concludes that the variables of individual, group, and team work behavior jointly influence teacher performance in SMAN 3 Medan. Thus, the fourth hypothesis in this study stated that "there is a positive and significant effect between the behavior of individuals, groups and team work on the teacher performance in SMAN 3 Medan

\section{CONCLUSION}

From the findings of this study, the first hypothesis resulted that there is a positive and significant effect between individual behavior (X1) on teacher performance $(\mathrm{Y})$ in SMA Negeri 3 Medan and the level of correlation is ignored, the score of the correlation coefficient is 0.147 , the strength of the relationship ( $\mathrm{R}$ Square )occurs between variables is 0.021 and the coefficient of determination (Adjusted R Square) is 0.009. It means that individual behavior influences the teacher performance into $0.9 \%$. Simply defined that if 
the individual behavior of each teacher in SMAN 3 Medan shows getting better in teaching and in their daily lives, it will automatically influence toward the increasing of teacher performance. An increasing of score from individual behavior will influence to the improvement of teacher performance.

For the second hypothesis, there is a positive and significant influence between group behavior (X2) on teacher performance (Y) in SMA Negeri 3 Medan with the level of correlation is ignored, the correlation coefficient score is 0.287 , the strength of the relationship ( $\mathrm{R}$ Square)occurs between variables is 0.082 and the coefficient of determination (Adjusted R Square) is 0.071. It means that group behavior has a positive influence on teacher performance in SMA Negeri 3 Medan around 7.1\%. Simply defines that if the behavior of a teacher group in SMA Negeri 3 Medan shows a good example for the students, teachers, and the school environment, it will increase teacher performance indirectly. The increasing of one score of teacher group will affect the improvement of teacher performance.

For the third hypothesis, there is a negative and insignificant influence between team work ( $\left.\mathrm{X}_{3}\right)$ on teacher performance (Y) in SMA Negeri 3 Medan with the level of correlation is ignored, the correlation coefficient shows 0.059 , the strength of the relationship ( $\mathrm{R}$ Square) occurr between variables is 0.003 and the coefficient of determination (Adjusted R Square) is (-o.oog). It indicates that team work has a negative influence toward the teacher performance in SMAN 3 Medan is -0.9\%. It means that if the teacher's work team looks good and solid in carrying out their professional duties, it will not have an effect on improving teacher performance.

Fourth hypothesis, there is a positive and significant influence between the behavior of individuals, groups, and teamwork on teacher performance in SMAN 3 Medan 3 by the low correlation, the correlation coefficient is 0.303 , the strength of the relationship between variables ( $\mathrm{R}$ Square) is 0.092 and the coefficient of determination (Adjusted R Square) is 0.057. It means that the influence of individual, group and team work behavior toward teacher performance in SMAN 3 Medan is $5.7 \%$ and the remaining is $94.3 \%$. It is caused from other factors and predicted from the variables do not included in this study.

\section{REFERENCES}

Amstrong and Baron, Performance Management- The New Realities, (London: Institute of Personnel and Development, 1998) 
Ashman, Karen K. Kirst, E-Book Human Behavior, Communities, Organizations, and Groups in the Macro Social Environment, (Belmont: Thomson, 2008)

Barnawi dan Mohammad Arifin, Kinerja Guru Profesional, (Yogyakarta: ArRuzz, 2014)

Fahmi, Irham, Manajemen Sumber Daya Manusia, (Bandung: Alfabeta, 2016)

Homans, George C, The Humans Group, Harcourt, Brace and World, (New York, 1950)

Luthans, Fred, Organizational Behavior Eleventh Editions, (New York: Mc Graw Hill Irwin, Campanies, Inc, 2008)

Robbins, Stephen dan Timothy A. Judge, Perilaku Organisasi: Konsep, Kontroversi, Aplikasi, (Jakarta: Prenhalindo, 2001)

Sedarmayanti, Sumber Daya Manusia dan Produktivitas Kerja, (Bandung: Mandar Maju, 2002)

Sopiah, Perilaku Organisasional, (Yogyakarta: Andi Offset, 2008)

Supardi, Kinerja Guru, (Jakarta: Rajawali Pers, 2013)

Surya, Muhammad, Psikologi Pendidikan, (Bandung: Remaja Rosdakarya, 2004)

West, Michael, Kerja Sama yang Efektif, Cetakan Kelima, penerjemah Srikandi Waluyo. (Yogyakarta: Penerbit Kaninus, 2002)

Zainal, Veithzal Rifai, dkk, Kepemimpinan dan Perilaku Organisasi. (Jakarta: Raja Grafindo Persada, 2014) 